\title{
NeOnatal Mortality of ElK IN AREaS WITH AND WITHOUT GRIZZLY BEARS
}

\author{
BRUCE L. SMITH $\downarrow$ NATIONAL ELK REFUGE $\downarrow$ JACKSON $\downarrow$ WY \\ KATHERINE C. MCFARLAND $\downarrow$ FRED G. LINDZEY \\ WYOMING COOPERATIVE RESEARCH UNIT \\ UNIVERSITY OF WYOMING $\downarrow$ LARAMIE
}

\section{ELIZABETH S. WILLIAMS $\downarrow$ WYOMING STATE VETERINARY LABORATORY \\ LARAMIE}

\section{$\downarrow \quad$ INTRODUCTION}

The Greater Yellowstone Ecosystem (GYE) may support the densest populations of elk in North America, and a diverse community of large carnivores that prey on elk. The Jackson elk herd has doubled in size since 1984 and currently exceeds its winter population objective of 11,000 elk by about 5,000 animals (Smith and Anderson 1998). In and adjacent to Grand Teton National Park (GTNP), mortality of neonatal of Jackson elk averaged 15\% annually during 1990-1992 (Smith and Anderson 1996). Predation by black bears and coyotes, when calves were less than 4 weeks of age, caused $68 \%$ of neonatal mortality. Calves killed by mountain lions were more than 4 months old. Except for hunting, predation was the largest source of mortality of radio-collared elk from birth through adulthood.

Since 1992, grizzly bear activity on federal cattle grazing allotments in eastern GTNP and the adjacent Spread Creek drainage of the Bridger-Teton National Forest (the East Study Area or East SA) has markedly increased and cattle losses to bears have become common. Personnel of the Wyoming Game and Fish Department attributed 26 cattle losses (25 calves, 1 cow) in the East SA in 1993 to grizzly bear predation. The Wyoming Game and Fish Commission, which compensates cattle producers for losses due to grizzly predation, initiated a study in 1994 to quantify the proportion of cattle losses in the East SA due to grizzly predation. One grizzly bear documented killing cattle each year, was captured and euthanized in GTNP in 1996.

Grizzly bears are opportunistic omnivores that consume both plant and animal foods (Blanchard et al. 1992). Grizzly bear predation on elk calves less than 4 weeks of age was the primary cause of mortality of calves and a major factor regulating the size of Yellowstone National Park's northern elk herd (Singer et al. 1997). Smith and Anderson (1996) found no evidence of grizzly predation on Jackson elk during 1990-1992. However, midsummer calf:cow ratios of elk in the Spread Creek area of eastern GTNP have declined since 1993. We initiated this study in 1997 to compare causes of elk calf mortality in the grizzly-occupied East SA and the relatively grizzly-free area of GTNP west of the Snake River (West SA). The objectives were to:

Quantify cause-specific neonatal mortality of elk calves, and learn if predation by colonizing grizzly bears has reduced neonatal survival of elk calves in Jackson Hole since 1992.

Compare neonatal mortality of elk between 
the East and West study areas to assess effects of grizzly bear occurrence on elk calf survival.

Assess if grizzly predation is compensatory or additive to other causes of mortality.

Determine if grizzly bears may be preying on elk calves in eastern GTNP and adjacent areas of Bridger-Teton National Forest and then switching to bovine calves after elk calves become too agile to be killed.

Through this research we seek to promote informed decision making by wildlife and land managers regarding the conservation and management of expanding populations of large carnivores and their prey. We intend to repeat this study after gray wolves have colonized Jackson Hole to evaluate their interaction with other large predators on a common prey, the Jackson elk, and to determine if colonizing predators may limit growth of the Jackson elk herd.

\section{$\downarrow \quad$ STUDY AREA}

The study was conducted in elk calving areas of the Jackson elk herd unit of northwest Wyoming described by Smith and Robbins (1994). The study occurred in portions of GTNP and the Bridger-Teton National Forest. Elevations range from 1,950 to $2,450 \mathrm{~m}$. Vegetation included sagebrush (Artemesia spp.) grasslands, and aspen (Populus tremuloides) woodlands, interspersed with willow (Salix spp.) riparian zones, and coniferous forests of lodgepole pine (Pinus contorta), Douglas fir (Pseudotsuga menziesii), and Engelman spruce (Picea engelmannii). The climate is characterized by long cold winters and warm short summers. The mean annual temperature is $1.7 \mathrm{C}$ and ranges from monthly means of $-11.0 \mathrm{C}$ in January to $14.7 \mathrm{C}$ in July (National Oceanic and Atmospheric Administration 1992).

\section{$\downarrow$ METHODS}

\section{Calf Capture and Marking}

Calves were captured from a Hiller 12-E helicopter contracted by Hawkins and Powers Aviation of Greybull, Wyoming. Although capture of calves by investigators on foot and horseback has been used in some studies, newborn elk calves are most efficiently located and captured from helicopter (M. Schlegel, Idaho Department of Fish and Game, pers. comm., Singer et al. 1997, Smith and Anderson 1996). We searched known calving locations within the two study areas and located parturient female elk and their newborn calves. When we spotted a bedded calf, we landed the helicopter as close as was safely possible, then stalked, captured, blindfolded, and hobbled the calf. We weighed, sexed, aged (Johnson 1951), and examined each calf for general physical condition. Blood was drawn from a sample of calves to compare physiological indices of calves that survived and died. Total handling time averaged 9.1 minutes per calf in 1997 and 8.5 minutes in 1998.

Calves were fitted with ear tag transmitters (Advanced Telemetry Systems, Inc., Insanti, MN). The transmitters remained silent while the calves were alive and active. When a transmitter remained immobile for $>3$ hours, a mortality switch initiated transmission of a continuous pulse signal. The transmitters donated to the study by Wyoming Game and Fish Department in 1997 were on just 4 frequencies. Consequently, 10-12 transmitters were deployed on each frequency in 1997. Thirty-six additional transmitters on 6 frequencies were purchased for the 1998 field season. Thus, transmitters were deployed on 10 frequencies in 1998.

\section{RADIO TRANSMITTER MONITORING AND MORTALITY INVESTIGATION}

The transmitters fitted to elk calves were monitored from 4 ground-based fixed towers mounted with twin 12 element yagi antennas. The calves were monitored at approximately 12-hour intervals from birth to 15 July. Two calves that migrated and died beyond the reception range of the ground-based towers were located during fixed-wing flights to radio track grizzly bears.

When a mortality signal was detected, investigators located and assessed the disposition of the calf as soon as possible (on average it took 2.3 days to locate each carcass in 1997 and 0.5 days in 1998). At mortality sites, standard forensic procedures were followed to determine presence of predators or scavengers (Singer et al. 1996, Smith and Anderson 1996). A thorough search of the transmitter's location was conducted to find evidence of predator hair, feathers, tracks and scat, evidence of struggle and location of attack, and all remains of 
the carcass. Field necropsies were performed on partially consumed carcasses. Hair samples were identified to species based on color, texture, and scale patterns of the medulla and cuticle (Moore et al. 1974). Tissue samples were collected and sent to the Wyoming State Veterinary Lab for diagnostic tests to evaluate animal condition and disease status. Intact carcasses were frozen and sent to Wyoming State Veterinary Lab for necropsy and diagnostic tests.

\section{GRIZZLY BEAR DISTRIBUTION}

To document presence of bears in both the West SA and the East SA, we constructed 12 hair collection corrals (HCCs) in which cattle blood was used as a nonreward bait (Table 1). The HCCs consisted of a single strand of barbed wire encircling 4-6 trees with a center tree in the middle. The barbed wire was stapled 20-22 inches above the ground on the outside perimeter of the trees. Poles were wired horizontally above the barbed wire to prevent ungulates from entering the HCCs and insure that bears would enter beneath the barbed wire. A 1-gallon milk jug, nearly filled with blood, was suspended by rope between 2 trees over the center of a HCC, beyond the reach of a tall bear. The Wyoming Game and Fish Department (1996) determined that cattle blood was the best attractant to lure bears into the HCCs. Jugs of cattle blood were replaced with fresh blood every 3 weeks.

Ten HCCs were constructed in late May 1997 and monitored once a week for 7 weeks from the last week of May through the second week of July in 1997. Two additional corals were constructed the second week of July and also monitored for 7 weeks. In 1998, all 12 HCCs were monitored from the first week of June through the third week of July. Additionally, 7 of the HCCS (Murie's Ridge, Timbered Island, Death Canyon, Granite Creek, Wolf Ridge, Wallace Draw, and Mary's Lake) were monitored through the end of September 1998 or first week of October to gather additional information on bear occurrence during late summer.

The HCCs were visited weekly. Hair samples were removed from the barbed wire, individually bagged, and submitted to the Wyoming Game and Fish Department Lab for species identification as described above.

Currently there are several studies in progress to sample grizzly bear populations in British Columbia and in the U.S. (Woods et al. 1994, Wyoming Game and Fish Department 1996). Those studies include collection of bear hair to extract DNA samples. Ongoing research in the GYE seeks to obtain statistically valid markrecapture population estimates of grizzly bears from microsatellite DNA markers in hair samples (Wyoming Game and Fish Department 1996). Hair samples we collect will be archived for this research effort.

\section{$\downarrow \quad$ RESULTS AND DISCUSSION}

\section{CALF MORTALITY}

During this second of 3 field seasons, we captured and radio eartagged 50 elk calves during 26 May--6 June 1998. We captured 23 calves (13 males, 10 females) in the East SA and 27 (11 males, 16 females) in the West SA. Nine of these died during June, 2 died in July, and 1 died in August. During a 29 May capture flight, one additional female calf was found freshly dead in the West SA. It was included in our capture sample, bringing the number of calves that died to 13 of $50(26 \% ; 1$ of 51 calves lost its eartag transmitter during the study) captured compared to 15 of $46(33 \%)$ that died in 1997.

Predation accounted for 10 of $13(77 \%)$ mortalities compared to 10 of $15(67 \%)$ in 1997 (Table 2). Two calves were killed by grizzly bears, both in eastern GTNP. Diagnostically useful tissues were collected from 4 of the 10 calves that were killed by predators. Brucella abortus was cultured from one of those calves that was killed by a black bear.

Two intact calves were recovered in the West SA. One died of congestive heart failure and had been born without a right ventricle. The other calf suffered from hemoperitoneum caused by torn or leaky umbilical blood vessels. During August, one calf was killed in an automobile collision.

\section{HAIR COLLECTION CORRALS}

A total of 273 hair samples were collected from the 12 HCCs (Table 1). Twenty-four samples were from Cervidae or Bovidae, 3 were from grizzly bears, and the remaining 246 samples were from black bears. Murie Ridge, Death Canyon, Granite 
Creek, and Lava Creek were visited most frequently by black bears. As in 1997, black bears may have entered and left the Murie Ridge, Lava Creek, and Granite Creek HCCs several times per week, based upon the large number of hair samples we collected on several occasions. Wallace Draw and Wolf Ridge HCCs received no visitations from bears, as in 1997. Three hair samples from grizzly bears were collected. One single hair was collected at the River Road corral. Two samples of hair were collected at the Mary's Lake HCC. No grizzly bear hair samples were collected from either the East or West SA in 1997.

\section{FIELD SEASON}

Because cause-specific mortality of neonatal elk can vary annually (Singer et al. 1997, Smith and Anderson 1996), we are seeking funding to continue the study a third and final year. In 1999 we intend to capture and radio tag approximately 25 elk calves in each of the West and East study areas. Eartag transmitters recovered from mortalities will be redeployed in 1999. Additional transmitters will be recovered by immobilizing all surviving radioed calves that winter on the National Elk Refuge during winter 1998-1999.

If sufficient funding is acquired for 1999 , 20 additional eartag transmitters will be purchased. Like the 36 purchased in 1998, the mortality switch will be programmed to continue transmitting once the transmitter is activated, rather than resetting to silent mode whenever it is moved, as was the case with all transmitters deployed in 1997 and 14 of 50 deployed in 1998 . Calf mortalities were located more rapidly in 1998 than in 1997 because of this design improvement. To insure that transmitters do not falsely activate on live elk, the delay period will be lengthened from 3 hours to 5 hours. More rapid investigation of mortalities improves success of determining cause of death of calves (Ballard et al. 1981, Larsen and Gauthier 1989).

HCCs should again be constructed and monitored in 1999. The corrals provide a means of measuring presence of black and grizzly bears in the 2 study areas. Radio collared grizzlies were known to have frequented the East SA during our monitoring period, and 2 calves were killed by grizzlies -- one each in June and July (Table 2). Yet only 3 hair samples were collected during a 12-17 week monitoring period. Some grizzly bears likely avoid entering HCCs. Others may simply not scent the bait as they pass through an area. It is also uncertain if we have achieved an optimum density of HCCs to attract grizzly bears in the two study areas. However, some patterns are emerging regarding relative activity of black bears, such as higher levels of black bear use of hair corrals in the West Study Area.

\section{ACKNOWLEDGMENTS}

This research was supported in 1997 and 1998 by the Rocky Mountain Elk Foundation, the University of Wyoming/National Park Service Research Center, the Community Foundation of Jackson Hole, Wildlife Forever, Grand Teton National Park, the National Elk Refuge, the Wyoming Cooperative Fish and Wildlife Research Unit, and the Wyoming Game and Fish Department. E. Bentley, A. Bethe, R. Leshan, M. McFarland, T. McFetters, S. Patla, and E. Pattison monitored elk transmitters and hair collection corrals, and assisted with mortality investigations. $T$. Moore, R. Grogan, and C. Anderson identified predator hair samples. M. Reid, D. Brimeyer, W. Long, S. Cain, S. Kilpatrick, D. Gomez, S. Brock, and H. Harlow assisted with calf captures. R. Hawkins and D. Hawkins, Hawkins and Powers Aviation, piloted the capture helicopter. G. Lust, Mountain Air Research, located elk mortalities from fixed-wing aircraft.

\section{$\uparrow \quad$ Literature Cited}

Ballard, W.B., Spraker, T.H., and Taylor, K.P. 1981. Causes of neonatal moose calf mortality in southcentral Alaska. J. Wildl. Manage. 45:335-342.

Blanchard, B. M., R. R. Knight, and D. J. Mattson. 1992. Distribution of Yellowstone grizzly bears during the 1980s Am. Midl. Nat. 128:332-338.

Johnson, D. E. 1951. Biology of the elk calf, Cervus canadensis nelsoni. J. Wildl. Manage. 15:396-410.

Larsen, D.G., and Gauthier, D.A. 1989. Effects of capturing pregnant moose and calves on calf survivorship. J. Wildl. Manage. 53:564567. 
Moore, T.D., Spence, L.E., and Dougnolle, C.E. 1974. Identification of dorsal guard hairs of some mammals of Wyoming. Wyoming Game and Fish Department, Bulletin 14. Cheyenne, Wyoming. 177pp.

National Oceanic and Atmospheric Administration. 1992. Monthly station normals of temperature, precipitation, and heating and cooling degree days, Wyoming, 1961-1990. National Oceanic and Atmospheric Administration, National Climatic Data Center, Asheville, N.C. 27pp.

Singer, F. J., A. T. Harting, and K. K. Symonds. 1997. Density-dependence, compensation, and environmental effects on elk calf mortality in Yellowstone National Park. Journal of Wildlife Management 61:12-25.

Smith, B.L., and S.H. Anderson. 1996. Patterns of neonatal mortality of elk in northwest Wyoming. Canadian Journal of Zoology 74:1229-1237.

Smith, B.L., and S.H. Anderson. 1998. Juvenile survival and population regulation of the Jackson elk herd. J. Wildl. Manage. 62:1036-1045.
Smith, B. L., and R. L. Robbins. 1994. Migrations and management of the Jackson elk herd. USDI Natl. Biol. Surv. Res. Publ. 1994. Wash. D.C.

Woods, J.G., A. Fonatan, T. Hamilton, J. Krebs, B. McLellan, and D. Peterson. 1994. West Slopes bear research project working plan 1993-1999. 27pp.

Wyoming Game and Fish Department. 1995. Grizzly bear-cattle interactions on the Blackrock/Spread Creek cattle allotment, Bridger-Teton National Forest and the Elk Ranch East cattle allotment, Grand Teton National Park. Wyoming Game and Fish Department, Lander, WY.

Wyoming Game and Fish Department. 1996. Effectiveness of attractants to lure grizzly bears into hair collection sites for future DNA fingerprinting - the Blackrock/Spread Creek area study. Wyoming Game and Fish Department, Lander WY. 
Table 1. Locations and number of hair samples collected from hair collection corrals in the East and West study areas during 1998. All corrals were monitored for at least 12 weeks, each designated by the numeric month and week of the month. Weekly frequency of visitation is shown throughout the sampling period and also for the 6week period from 1 June to mid-July.

\begin{tabular}{|c|c|c|c|c|c|c|}
\hline Corral Name & Study Area & Species & $\begin{array}{l}\text { Dates Hair } \\
\text { Collected }\end{array}$ & $\begin{array}{l}\text { Samples per } \\
\text { Date }\end{array}$ & $\begin{array}{l}\text { Frequency } \\
\text { of visitation } \\
\text { throughout } \\
\text { sampling } \\
\text { period1 }\end{array}$ & $\begin{array}{l}\text { Frequency of visitation, } \\
\text { June-mid-July ( } 6 \text { weeks) }\end{array}$ \\
\hline Murie Ridge & West & $\begin{array}{l}\text { Black } \\
\text { bear }\end{array}$ & $\begin{array}{l}6-1,6-2,6-3, \\
7-1,7-2,7-4, \\
8-1,8-4,9-1, \\
9-2,9-3,9-4, \\
10-1\end{array}$ & $\begin{array}{l}5,5,11, \\
15,9,3,8, \\
11,4,17,5, \\
8,1\end{array}$ & 0.76 & 0.83 \\
\hline $\begin{array}{l}\text { Timbered } \\
\text { Island }\end{array}$ & West & $\begin{array}{l}\text { Black } \\
\text { bear }\end{array}$ & $\begin{array}{l}7-4,9-2,9-3, \\
9-4\end{array}$ & $5,6,1,1$ & 0.24 & 0.17 \\
\hline Burned Ridge & West & $\begin{array}{l}\text { Black } \\
\text { bear }\end{array}$ & $\begin{array}{l}6-3,6-4,7-2, \\
7-3\end{array}$ & $2,3,3,16$ & 0.25 & 0.67 \\
\hline RKO Road & West & $\begin{array}{l}\text { Black } \\
\text { bear }\end{array}$ & $6-1,8-1$ & 1,1 & 0.12 & 0.17 \\
\hline River Road & West & $\begin{array}{l}\text { Black } \\
\text { bear }\end{array}$ & $7-4$ & 6 & 0.06 & 0 \\
\hline River Road & West & $\begin{array}{l}\text { Grizzly } \\
\text { bear }\end{array}$ & $7-4$ & 1 & 0.06 & 0 \\
\hline $\begin{array}{l}\text { Death } \\
\text { Canyon }\end{array}$ & West & $\begin{array}{l}\text { Black } \\
\text { bear }\end{array}$ & $\begin{array}{l}8-4,9-1,9-2, \\
9-3,9-4,10- \\
1\end{array}$ & $\begin{array}{l}1,3,4,2 \\
3,1\end{array}$ & 0.35 & 0 \\
\hline Granite Creek & West & $\begin{array}{l}\text { Black } \\
\text { bear }\end{array}$ & $\begin{array}{l}6-1,7-1,8-1, \\
8-2,8-4,9-3, \\
9-4,10-1\end{array}$ & $\begin{array}{l}13,3,5 \\
11,1,2,1\end{array}$ & 0.47 & 0.33 \\
\hline Three Rivers & East & $\begin{array}{l}\text { Black } \\
\text { bear }\end{array}$ & $6-1,7-4$ & 2,4 & 0.12 & 0.17 \\
\hline Wolf Ridge & East & $\begin{array}{l}\text { Black } \\
\text { bear }\end{array}$ & & & 0 & 0 \\
\hline Lava Creek & East & $\begin{array}{l}\text { Black } \\
\text { bear }\end{array}$ & $\begin{array}{l}6-1,6-2,6-3, \\
6-4,7-4\end{array}$ & $\begin{array}{l}4,15,4,1, \\
1\end{array}$ & 0.31 & 0.67 \\
\hline $\begin{array}{l}\text { Wallace } \\
\text { Draw }\end{array}$ & East & $\begin{array}{l}\text { Black } \\
\text { bear }\end{array}$ & & & 0 & 0 \\
\hline Mary's Lake & East & $\begin{array}{l}\text { Black } \\
\text { bear }\end{array}$ & $8-4$ & 2 & 0.08 & 0.17 \\
\hline Mary's Lake & East & $\begin{array}{l}\text { Grizzly } \\
\text { bear }\end{array}$ & $6-1$ & 2 & 0.08 & 0.17 \\
\hline
\end{tabular}

1 June through the first week of October: Murie's Ridge, Timbered Island, Death Canyon, Granite Creek; June through September: Burned Ridge, RKO Road, River Road, Three Rivers, Lava Creek; June through August: Wolf Ridge, Wallace Draw, Mary's Lake 
Table 2. Mortality of radio eartagged elk calves that were captured in the East and West study areas during 1998. Calves died west of the Snake River in Grand Teton National Park (W. GTNP), or east of the Snake River in eastern GTNP (E. GTNP) or east of GTNP on theBridger-Teton National Forest.

\begin{tabular}{|l|l|l|l|l|l|l|l|}
\hline $\begin{array}{l}\text { Calf } \\
\text { No. }\end{array}$ & Sex & Capture Area & $\begin{array}{l}\text { Mortality } \\
\text { Location }\end{array}$ & $\begin{array}{l}\text { Date } \\
\text { Detected }\end{array}$ & $\begin{array}{l}\text { Date } \\
\text { Retrieved }\end{array}$ & $\begin{array}{l}\text { Probable Cause } \\
\text { of Death }\end{array}$ & $\begin{array}{l}\text { Predisposing } \\
\text { Conditions }\end{array}$ \\
\hline 347 & M & East & E. GTNP & $6-11$ & $6-11$ & Black bear & Brucellosis \\
\hline 359 & M & West & W. GTNP & $8-25$ & $8-26$ & Roadkill & \\
\hline 367 & F & West & W. GTNP & $6-2$ & $6-3$ & $\begin{array}{l}\text { Congestive heart } \\
\text { failure }\end{array}$ & $\begin{array}{l}\text { Developmental } \\
\text { failure heart } \\
\text { defect }\end{array}$ \\
\hline 368 & F & West & W. GTNP & $5-29$ & $5-29$ & Hemoperitoneum & Torn umbilicus \\
\hline 369 & F & East & E. GTNP & $6-2$ & $6-2$ & Probable bear & (sp. unknown) \\
\hline 374 & F & East & E. GTNP & $6-3$ & $6-4$ & Grizzly bear & \\
\hline 377 & F & West & W. GTNP & $6-12$ & $6-13$ & Black bear & \\
\hline 379 & M & West & W. GTNP & $6-10$ & $6-10$ & Mountain lion & \\
\hline 383 & M & West & W. GTNP & $7-22$ & $7-22$ & $\begin{array}{l}\text { Unknown } \\
\text { predator }\end{array}$ & \\
\hline 387 & M & East & E. GTNP & $6-11$ & $6-11$ & Black bear & \\
\hline 388 & F & East & E GTNP & $7-19$ & $7-20$ & Grizzly bear & Lesions from \\
\hline & & & GTNP & & & difficult birth & \\
\hline 394 & F & East & E. GTNP & $6-8$ & $6-8$ & $\begin{array}{l}\text { Probable black } \\
\text { bear }\end{array}$ & \\
\hline 397 & M & East & E. GTNP & $6-10$ & $6-12$ & Black bear & . \\
\hline
\end{tabular}

